\title{
INHERITANCE OF COLOR IN THE EGGPLANT
}

\author{
(Solanum melongena $\mathrm{L})^{1}$
}

\author{
J. A. B. NolLA"
}

The purpose of this investigation has been to obtain some knowledge of the behavior of color of our so-called native eggplants toward that of the imported Black Beauty and. New York Improved as this would be very useful in connection with simultaneous studies on the production through hybridization of eggplants resistant to the bacterial wilt (Phytomonas solanaceara (E. F. Sm.) Comm. S.A.B.). The Black Beauty is generally very susceptible to this disease, but it was discovered in preliminary trials by the author in 1923 and 1924 that one of the native varieties was more resistant to the disease than any of the imported varieties. However, this native fruit is of undesirable color and shape for commercial purposes.

The factors which have been studied in this investigation are: color of plant, of fruit and of flower, and the striped character of the anthers.

The first studies on eggplant hybridization seem to have been made by Bailey and Munson (3) and were reported in 1891. The results published then were on the $\mathrm{F}_{1}$ generation and showed that purple color of both fruit and foliage is dominant over green. In the following year Professor Bailey (2) gave results of some $\mathrm{F}_{2}$ and backcross data. In a progeny of 175 plants from a self-fertilized $F_{1}$ individual he found 83 green and 92 purple plants, a result which would indicate a 9:7 ratio. According to this ratio, two factors should be assumed for color of plant both of which would be necessary for the development of purple color. In the same $\mathrm{F}_{2}$ population 102 plants came into fruit, 48 of which were colored and 54 green or white. These numbers are contradictory since greens appear to be in excess of purples. It is plain that the numbers were too small to give conclusive results; a larger population would have been more reliable. In two other $\mathrm{F}_{1}$ fruits $\mathrm{A} 5$ and $\mathrm{A} 6$, self-pollinated like the preceding one, the results taken together show 299 purple plants to 208 recessive, another indication of a $9: 7$ ratio.

${ }^{1}$ Presented as a rartial fulfillment of the minor requirements for the degree of Doctor of Philosopiny at Corn 1 University.

2 Formerly of the Insular Experiment Station, now in the Graduate School at Cornell University, Ithaca, N. Y. 
In a fourth $\mathrm{F}_{1}$ fruit (A8), not artificially pollinated nor bagged, the resulting $\mathrm{F}_{2}$ generation gave 105 purple and 69 green plants. This was presumably naturally selfed although it may have been pollinated by insects. Here again, like the preceding, the results appear to indicate a 9:7 ratio for plant color.

In the backcross results conditions are, in a way, different. The backeross progeny of A 2 gave 82 green plants and 21 purples, that of A7 gave 101 greens to 143 purples. These should be expected to be similar in both progenies, but this is not the case. In the former, a 1:3 backeross ratio confirms the $9: 7$ ratio in the $\mathrm{F}_{2}$. In the latter, however, the purples are in excess of the greens, an observation which appears to be contrary to the expected $1: 3$ ratio.

The results of fruits A 3 and A 4 which were the product of the pollination of $\mathrm{F}_{1}$ with the dominant Black Pekin, are as would have been expected, all purple plants.

Finally, the results for the eight progenies are given together, and are therefore of no value from the standpoint of the analysis of color.

Two other crosses, Giant Round Purple $\times$ White Chinese and Long White $\times$ Black Pekin, are also reported but the populations in all of the $\mathrm{F}_{2}$ or backeross progenies are too small to be of value in determining ratios.

Munson (6) in 1892 reported further on the above crosses. This same writer, later in 1905 (7) commenting on eggplant crossing further reaffirms the dominance of purple color of fruit over white; but makes no other contribution to the knowledge of inheritance in this plant. It must be remembered that Mendel's epoch-making studies on inheritance had already been discovered at the time of this later publication.

Owen (9), in 1912 reported on the $\mathrm{F}_{2}$ generation data of cross. Long White $\times$ Dwarf Purple and in a population of 90 plants found 59 with purple stems to 31 with green stems.

Here again a 9:7 ratio shows a behavior for plant color similar to that reported by Bailey and Munson. It is of interest to note that all the green-stemmed plants bore either greenish white or ivory fruits, colors which are recessive to purple or violet. This indicates a possible linkage of recessive factors for plant and fruit color or a single gene that affects both plant and fruit color. The purplestemmed plants bore purple or violet fruit.

The same writer (10) again in 1917 gave some data on $\mathrm{F}_{2}$ generations of crosses made in previous years but the numbers are very 
small. He, however, points again to the dominance of purple color of fruit over green.

Halsted (5) found a 3:1 ratio of green to white color of flesh and a similar ratio of purple to colorless skin (Green purple $X$ White colorless). In the cross Long White $\times$ Dwarf Purple he obtained a $9: 3: 3: 1$ ratio of purple, green, pink and white skin. For this proportion a two-factor hypothesis should be assumed, the two dominant factors producing purple, the absence of the first producing green color, that of the second pink color, and the absence of both dominant factors resulting in the production of white fruits. It must be remembered that in the same cross, Owen (9) had obtained results for plant color which agree with the $9: 7$ ratio.

Bayla (1) gave results of a cross between a Purplish Native Elongated $\times$ New York Improved. From his work would seem that direct and reciprocal crosses do not give similar $\mathrm{F}_{1}$ progenies. His study of the $\mathrm{F}_{2}$ generation is very incomplete; he speaks about the $\mathrm{F}_{2}$ hybrid, but no attempt is made at the study of the inheritance of color or any other character. Segregation is not studied in this generation.

In general, the data secured by the early investigators were insufficient for a complete analysis of the inheritance of color in the eggplant. The best data seem to be those given by Bailey and Munson (3) who were the only ones to make use of the backeross method. Summarizing these investigations it may be said that data have been offered suggesting a $9: 7$ ratio for plant color and $9: 7,9: 3: 3: 1$ and $3: 1$ ratio for fruit color and a $3: 1$ ratio for color of flesh.

It is the purpose of this paper to present the results of our studies on the inheritance of color of plant, fruit, and corolla, and the redstriped character of the anthers. In this connection purple color of plant has been studied as against green color, purple or violet corolla against white corolla, striped against non-striped anthers, purple fruit color in contrast to green or white and green color against white.

\section{MATERIALS USED}

The most important characters of the native eggplants used in these studies are given in table I. (See half-tone plates.)

It should be noted that the anther saes burst as follows: in the varieties Fajardo, White Pompadour and Long Purple K, just before expansion of the corolla; in Camuy, Black Beauty, University and Green, during or after the corolla opens. 


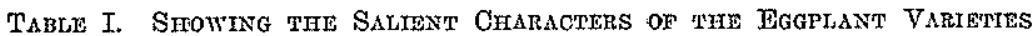
USED IN THIS PAPER

\begin{tabular}{|c|c|c|c|c|c|c|}
\hline \multirow[b]{2}{*}{ Variety } & \multicolumn{2}{|c|}{ Plant Color } & \multirow[b]{2}{*}{$\begin{array}{l}\text { Fruit } \\
\text { color }\end{array}$} & \multirow[b]{2}{*}{$\begin{array}{c}\text { Corolla } \\
\text { color }\end{array}$} & \multicolumn{2}{|c|}{ Anthers } \\
\hline & $\begin{array}{l}\text { Seedling } \\
\text { stage }\end{array}$ & $\begin{array}{l}\text { Adult } \\
\text { plant }\end{array}$ & & & Striped & $\begin{array}{l}\text { Non- } \\
\text { sptriped }\end{array}$ \\
\hline Fajardo.. & Green & Light & $\begin{array}{l}\text { Green } \\
\text { purple } \\
\text { striped }\end{array}$ & $\begin{array}{l}\text { Viola- } \\
\text { ceous }\end{array}$ & & $x$ \\
\hline Camuy.. & $\begin{array}{l}\text { Dark } \\
\text { purplo }\end{array}$ & $\begin{array}{c}\text { Dark } \\
\text { purple }\end{array}$ & $\begin{array}{r}\text { Rer to vi. } \\
\text { olaceous }\end{array}$ & $\begin{array}{c}\text { Drep vi- } \\
\text { olaceous }\end{array}$ & $\mathrm{x}$ & \\
\hline White Pompadour......... & $\begin{array}{l}\text { Green or } \\
\text { light } \\
\text { purple }\end{array}$ & $\begin{array}{l}\text { Light } \\
\text { Ptirple }\end{array}$ & $\begin{array}{l}\text { White } \\
\text { purple } \\
\text { striped }\end{array}$ & $\begin{array}{c}\text { Viola- } \\
\text { coous }\end{array}$ & & $x$ \\
\hline University................. & Purple & Purple & Pink & Violaceous & $x$ & \\
\hline Green....................... & Green & Green & Green & White & & $x$ \\
\hline Blnck Beauty... & $\mathrm{L}_{\text {Pight }}^{\text {Purple }}$ & $\begin{array}{l}\text { Light } \\
\text { Purple }\end{array}$ & Purplo & $\begin{array}{l}\text { Viola- } \\
\text { ceous }\end{array}$ & $\mathrm{x}$ & \\
\hline
\end{tabular}

The first planting of some of the varieties was made in the fall of 1926 and some crosses made the succeeding winter of 1926-27. Only a few of the crosses were made that season because not all of the varieties had been secured. Gradually additions were made to the collection and new crosses made. The first generation of the 1926-27 crosses was grown in the summer of 1927 , and $F_{2}$ and backcross generations planted in the fall of that same year, and data gathered early in 1928. When possible two generations were grown in the same year.

Emasculations were made as short a time before the bursting of the anthers as possible, which was the day previous to the opening of the corolla in all varieties except Fajardo, Long Purple $\mathrm{K}$ and White Pompadour where it was necessary to emasculate two days in advance of corolla opening. Pollinations were made as soon as the corollas were expanded. In the removal of the anthers and in the pollinating operations, the flowers were disturbed as little as possible to avoid unnecessary injury and consequent blasting of the fruits. They were properly bagged and tagged. The bags were removed after the young fruit had set, usually five or six days after pollination. All selfing was made by covering up the blossoms with glassine bags before expansion of the corolla.

The fruits were gathered when there was evidence of the yellow coloration on them and seed was cleaned immediately, dried in the shade and stored in mason jars in which a beaker of ealcium chloride had been placed. There is little difficulty with the viability of the seed under such storage conditions. 
The seed were sown in ordinary greenhouse flats from which 2-to 3-week-old plants were transplanted to other plots, allowing 12 to 16 square inches of soil per plant. The plots were carefully labeled to avoid any possible errors. With a reasonable amount of care the loss from transplanting was negligible.

It was soon found that plant color could be determined at the time when the seedlings were transplanted. The seedlings of the White Pompadour and the Fajardo do not develop any purple color before the second week and those of the Green variety are pure green from the beginning. In seedlings of the Black Beauty, color was evident after the first week and in those of Camuy and University it appears very early. Thus, in crosses in which any of the first three was involved with any of the remaining varieties, the seedlings were classed in two groups as colored and colorless (green). (See color plate III).

The sorting of seedlings presents no difficulty when the cross is between Green and any variety with purple seedlings, but when Green is crossed with either Fajardo or White Pompadour some difficulty is experienced making it necessary, with certain individuals, to make the final classification when the plants are transferred to the field. In the large seedlings ( 5 to 6 pairs of leaves) the purple color begins to appear in spots on the stem; but usually first on the main veins at the base of the leaf blade or on the petiole. In crosses between Fajardo or White Pompadour and any of the colored varieties the sorting out must be done early before any coloration shows in the recessive seedlings; if one waits too long they will be indistinguishable from the dominant ones.

The varieties given in the order of intensity of color of seedlings is as follows: Camuy, University, Black Beauty, White Pompadour and Fajardo.

If counts for plant color made in the seedbed on any given eross were confirmed by later field observations, duplicate crosses were carried only through the seedbed and there discarded.

Plantings in the field were made in rows three and one-half feet apart. Each row was numbered consecutively and the serial number kept season after season, starting with the second generation in 1927-28. A record was kept of each individual plant throughout the entire investigation making reference to row number and plant number. In this way it was very easy to trace back the history of any one of the many thousand seedlings grown in later generations.

Our data secured from $\mathrm{F}_{2}$ 's and backcrosses are given below. 
Under plant color will be presented the study of the inheritance of the purple color in the different varieties. Since it was desirable to know whether the variations in color in the several varieties were really different, most of the varieties were tested with Green where the color remains constant throughout the entire life of the plant and with Fajardo where the green color changes to light purple during the seedling stage.

Table II shows the data on plant color in the various crosses. Observed numbers have been calculated on the basis of a $3: 1$ ratio and are also given in table II. Likewise, deviations from the observed numbers and probable errors, are also given.

In every case purple color was dominant over the green of either Fajardo or Green; the $F_{1}$ plants in all the crosses were purple.

The different shades of purple found in Camuy, Black Beauty and University reacted similarly toward Green. A second green found in Fajardo when crossed with University purple gave results similar to those secured in crosses of Green with purple varieties. It should be remembered that the Fajardo green is in reality a purple which does not appear until two or three weeks after the seedlings emerge.

Table II. Showing Plant Color Data on $\mathrm{F}_{2}$ and Backcross of the VARIOS CROSSES.

\begin{tabular}{|c|c|c|c|c|c|c|c|}
\hline \multirow{2}{*}{ Progeny } & & \multicolumn{2}{|c|}{ Observed } & \multirow{2}{*}{$\begin{array}{l}\text { Calcu- } \\
\text { lated }\end{array}$} & \multirow{2}{*}{$\begin{array}{l}\text { Devia- } \\
\text { tion }\end{array}$} & \multirow{2}{*}{ P. E. } & \multirow{2}{*}{ D/P. E. } \\
\hline & & $\mathrm{n}$ & ratio & & & & \\
\hline $1-\mathrm{Ca} \times \mathrm{Gr} \ldots \ldots \ldots$ & Purple. & 885 & $2.94: 1$ & 889.50 & 4.5 & \pm 10.06 & 0.447 \\
\hline $2-\mathrm{Gr} \times \mathrm{Ca}_{3}$. & Preen...... & $\begin{array}{r}301 \\
1592\end{array}$ & $3.19: 1$ & $\begin{array}{r}296.50 \\
1580.25\end{array}$ & 11.75 & \pm 13.4 & 0.87 \\
\hline $3-(\mathrm{Ca} \times \mathrm{Gr}) \times \mathrm{Gr} . .$. & $\begin{array}{l}\text { Green...... } \\
\text { Purple.... }\end{array}$ & $\begin{array}{l}515 \\
149\end{array}$ & 1.09:1 & $\begin{array}{l}526.75 \\
143\end{array}$ & 6.0 & \pm 5.70 & 1.05 \\
\hline $4-\mathrm{Gr}_{\mathrm{r}} \times \mathrm{BB} \ldots \ldots$ & $\begin{array}{l}\text { Green...... } \\
\text { Purple.... }\end{array}$ & $\begin{array}{r}137 \\
2404\end{array}$ & $2.80: 1$ & $2446: 50$ & 42.5 & \pm 16.68 & 2.55 \\
\hline $5-\mathrm{BB} \times \mathrm{Gr}$. & $\begin{array}{l}\text { Green...... } \\
\text { Purple.... }\end{array}$ & $\begin{array}{l}858 \\
442\end{array}$ & $2.73: 1$ & $\begin{array}{l}815.50 \\
453\end{array}$ & 11.0 & \pm 7.17 & 1.39 \\
\hline $6-(\operatorname{Gr} \times \mathrm{BB}) \times \mathrm{Gr}$. & $\begin{array}{l}\text { Green ....... } \\
\text { Purple.... }\end{array}$ & $\begin{array}{l}162 \\
121\end{array}$ & $1.15: 1$ & & $\ddot{8} .0$ & \pm 5.07 & 1.58 \\
\hline $7-(\mathrm{BB} \times \mathrm{Gr}) \times \mathrm{Gr}$ & $\begin{array}{l}\text { Green....... } \\
\text { Purple.... }\end{array}$ & $\begin{array}{l}105 \\
169\end{array}$ & $1.17: 1$ & & 12.0 & \pm 5.98 & 2.0 \\
\hline 8-Univ. $x \mathrm{~F}$. & Green...... & $\begin{array}{l}145 \\
106\end{array}$ & $3.42: 1$ & $\begin{array}{l}157 \\
102.75\end{array}$ & 3.25 & \pm 3.42 & 0.95 \\
\hline & $\begin{array}{l}\text { Green- } \\
\text { striped }\end{array}$ & 31 & & 34.25 & & & $\cdots$ \\
\hline 9-F $\times$ Univ... & $\begin{array}{l}\text { Purple...... } \\
\text { Green-.. } \\
\text { striped }\end{array}$ & $\begin{array}{r}213 \\
65\end{array}$ & $\begin{array}{r}3.28: 1 \\
\ldots \ldots \cdots\end{array}$ & $\begin{array}{r}208.50 \\
69.50\end{array}$ & $\begin{array}{r}4.50 \\
\ldots \ldots+\cdots\end{array}$ & $\begin{array}{r} \pm 4.87 \\
\ldots \ldots \cdots\end{array}$ & $\begin{array}{r}0.92 \\
\cdots \cdots\end{array}$ \\
\hline 10-Univ. x Gr. & $\begin{array}{l}\text { Purple..... } \\
\text { Green..... }\end{array}$ & $\begin{array}{r}152 \\
38\end{array}$ & $\begin{array}{l}4: 1 \\
\cdots\end{array}$ & $\begin{array}{r}142.50 \\
47.50\end{array}$ & 9.50 & $\begin{array}{l} \pm 4.03 \\
\ldots \ldots \ldots\end{array}$ & 2.36 \\
\hline 11-Gr x Univ.... & $\begin{array}{l}\text { Purple.... } \\
\text { Green..... }\end{array}$ & $\begin{array}{r}191 \\
67\end{array}$ & $2.85: 1$ & $\begin{array}{r}193.50 \\
64.50\end{array}$ & 2.50 & \pm 4.69 & 0.53 \\
\hline 12-(Univ. $x$ Gr) $x$ Gr. & $\begin{array}{l}\text { Purple..... } \\
\text { Green.... }\end{array}$ & $\begin{array}{l}50 \\
54\end{array}$ & $\begin{array}{l}0.93: 1 \\
0 \ldots \ldots\end{array}$ & $\begin{array}{l}52.00 \\
52.00\end{array}$ & $\ddot{2} \ddot{0}$ & \pm 3.44 & 0.0 .58 \\
\hline 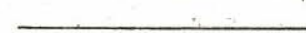 & & & & & & & \\
\hline
\end{tabular}


It can be generally said that observations agree fairly well with expectations on the basis of a 3:1 ratio of purple to green color of the variety Green (progenies 1-7 and 10-12). In every case the deviation is less than three times the probable error and, therefore, should be considered insignificant and can be attributed to random sampling. The green of Fajardo reacted in a similar way toward purple (progenies 8 and 9).

No progenies of backcrosses of Univ. $X F$ have been produced. The first attempt was frustrated by damping-off of the seedlings of the only two progenies that germinated; a second attempt last summer was unsuccessful because of the very few seedlings that germinated. Consequently the evidence offered for a $3: 1$ ratio of purple to this green is based only on $\mathrm{F}_{2}$ progenies.

It is clear that the different shades of purple found in the varieties Camuy, Black Beauty and University react similarly toward Green. A second green (Fajardo) when crossed with University, gave results similar to those secured in crosses of Green with purple varieties.

The assumption of one unit factor pair $\mathrm{Pr} p r$ for plant color will explain satisfactorily the results obtained.

\section{FRUIT, ANTHER AND COROLLA COLOR}

The study of inheritance of fruit color has involved the behavior of purple, red, pink, green purple striped and white purple striped. In corolla color we have been concerned with violet, purple and white and in stamen color we have dealt with red striped and non-striped anthers. In the preceding pages the data on plant color has been presented for four crosses. Our observations in those crosses have shown that green color of fruit is always associated with green plant color and purple, red and pink with purple color of plants. In the ease of color of corolla it was found that white corolla was always associated with green color of plant in all the crosses. The non-striped character of the anthers always indicated recessiveness of fruit or plant color. Thus, in cases of crosses with Fajardo where corolla is colored and fruit is green, the recessive plants (green) always bore green fruit and non-striped anthers. In crosses with Green as a parent the green plants always bore green fruit, white corolla and non-striped anthers.

Therefore, the data and conclusions used in the analysis of plant color, will be the same for these characters. 


\section{FRUIT COLOR}

In the crosses $C a \times G r$ (red $\times$ green), $\mathrm{BB} \times \mathrm{Gr}$ (purple $\times$ green $)$ and Univ. $X \mathrm{Gr}$ (pink $\times$ green) a $3: 1$ ratio was found for plant color and since green fruit color was associated with green plant color the same ratio must apply to fruit color in these crosses.

In the cross Univ. $\times F^{\prime}$ (pink $\times$ green purple striped) a similar relation was found; all the plants sorted in seedbed as green bore green purple striped fruit.

Crosses between Black Beauty and Fajardo were made twice, but the $\mathrm{F}_{2}$ and backcross data were not sufficient to arrive at proper conclusions as to ratio of inheritance. They proved, however, absolute dominance of purple over green fruit color.

In order to determine the relation of purple and green purple striped to white purple striped, Black Beauty (purple) and Fajardo (green purple striped) were crossed with White Pompadour (white purple-striped). Part of the progenies of the first cross was lost but dominance of purple was proved.

The results of the last cross appear in the following table.

Table III. Fruit Color.

\begin{tabular}{|c|c|c|c|c|c|c|c|}
\hline \multirow{2}{*}{ Progeny } & & \multicolumn{2}{|c|}{ Observed } & \multirow{2}{*}{$\begin{array}{l}\text { Calcu- } \\
\text { lated }\end{array}$} & \multirow{2}{*}{$\begin{array}{c}\text { Devia- } \\
\text { tion }\end{array}$} & \multirow{2}{*}{ P. E. } & \multirow{2}{*}{$\mathrm{D} / \mathrm{P} . \mathrm{E}$. } \\
\hline & & $\mathrm{n}$ & ratio & & & & \\
\hline $13-\mathrm{Wh} . \mathrm{P} \times \mathrm{F}, \ldots \ldots \ldots \ldots$ & Green...... & $\begin{array}{r}116 \\
29\end{array}$ & $\ldots \ldots 4.1$ & $\begin{array}{r}108.75 \\
36.25\end{array}$ & 7.25 & \pm 3.52 & 2.05 \\
\hline $14-F, x$ Wh. P............ & $\begin{array}{l}\text { Green....... } \\
\text { White.... }\end{array}$ & $\begin{array}{r}120 \\
49\end{array}$ & $3.44: 1$ & $\begin{array}{r}126.75 \\
42.25\end{array}$ & 6.75 & \pm 3.79 & 1.78 \\
\hline 15-(F. $\times$ Wh. P.) $x$ Wh. P. & $\begin{array}{l}\text { Green....... } \\
\text { White.... }\end{array}$ & $\begin{array}{l}127 \\
141\end{array}$ & $1.1: 1$ & $\begin{array}{l}134 \\
134\end{array}$ & 7.00 & \pm 5.52 & 1.28 \\
\hline
\end{tabular}

The evidence of $\mathrm{F}_{2}$ data in the above table supports the assumption of a $3: 1$ ratio of green purple striped to white purple striped fruit. The backeross data furnish additional confirmation of expected results.

Summarizing the observations on fruit color it may be concluded that the red, pink and purples are dominant over green, green purple striped and white purple striped, but green purple striped was dominant over white purple striped. A 3:1 ratio was obtained with purple, red and pink in relation to green; a similar ratio between white purple striped and green purple striped. Therefore, one unit character produces color of fruit. It may be represented by $C c$.

It should be remembered in closing, that certain unexplained observations were made in some of the $\mathrm{F}_{2}$ progenies. In the $\mathrm{F}_{2}$ of Univ. $\times \mathrm{F}$, five plants with white purple striped fruits were found. 
and classed with green for the purpose of the relation of pink to green. When perpetuated they have been found to breed true; i. e. the fruit is always white purple striped. In every other respect they are like Fajardo (green fruited) plants. Both University and Fajardo are true breeding varieties and therefore the appearance of these white purple striped fruit-bearing plants has been a matter of much interest to us during the whole time this work has been in progress. Things appeared still more complicated when two plants with these white purple striped fruits were discovered in the cross $\mathrm{F} \times$ Univ.

This phenomenon is, to our mind, of much interest since it may throw some light on the true nature of the variety Fajardo which, as reported to us, arose in a graft of a white eggplant on Solanum torvum. The only difference between the new puzzling individuals and Fajardo individuals lies in the color of fruit; color of plant, corolla, and anthers, and shape of fruit are like in the Fajardo. In no case was an individual with white fruits obtained in any of many progenies of selfed Fajardo fruits.

The writer would make further studies with these interesting whites if it should be possible in the future.

It should be noted, in passing, that the observations of other writers in this respect are of interest. Owen (8) in 1912, for instance, in the $\mathrm{F}_{2}$ of a cross where white and purple color were involved found greenish white fruited plants, and Halsted (4) in the same cross obtained greens again in a proportion of $3: 1$ toward the whites and even pink-colored fruits. The pink color in Halsted's may be explained as a dilution of the purple in the Dwarf Purple parent.

\section{COLOR OF COROLLA}

In these studies purple or violet (colored) corolla has been contrasted to white (non-colored).

In the direct and reciprocal crosses $\mathrm{Ca} \times \mathrm{Gr}, \mathrm{BB} \times \mathrm{Gr}$ and Univ. $X \mathrm{Gr}$ it was found in the $\mathrm{F}_{2}$ and backeross progenies that white corolla was always associated with green color of plant and fruit. Consequently the same general conclusions in the genetical analysis can be drawn for color of corolla as for plant and fruit color, namely that a $3: 1$ relation exists between color and no color and that colored corolla is due to one unit factor which may be represented by $\mathrm{C}_{1}$ and white color by its absence and represented by $\mathrm{C}_{1}$. 


\section{STRIPING AND NON-STRIPING OF ANTHERS}

Striped anthers occur in the parents Black Beauty, University, Camuy and non-striped anthers in White Pompadour, Fajardo and Green.

In the crosses $\mathrm{Ca} \times \mathrm{Gr}, \mathrm{BB} \times \mathrm{Gr}$, Univ. $\times$ Gr. and Univ. $\times \mathrm{F}$, the absence of the stripes on the anthers was evident in the plants with the green fruits and in the first three of these crosses it was associated not only with green color of fruits but also with green plants and white corollas. In the cross Wh. P. $\times \mathrm{F}$ where both parents had non-striped anthers, the $\mathrm{F}_{1}, \mathrm{~F}_{2}$ and backeross progenies had all non-striped anthers. Hence, the same conclusions will hold for striping of anthers as for plant, fruit and corolla color. A unit factor will be assumed and represented as $S t$ with its recessive allelomorph $s t$.

\section{SUMMARY AND CONCLUSIONS}

(1) Inheritance studies on the color in the eggplants have been made by various investigators but the first one to attempt an analysis was Halsted (5) who reported a 3:1 ratio of green to white color of flesh and a similar ratio of purple to colorless skin; also a $9: 3: 3: 1$ ratio of purple, green, pink, and white fruit. Several workers have pointed out the dominance of purple color over white in fruits. Bayla (1) apparently regarded $\mathrm{F}_{1}$ generations of reciprocal crosses as dissimilar.

(2) The methods employed in the various crosses are given.

(3) Seedlings in some of the crosses could be classified according to their color during the very early stages. Plants of the Green variety remain green throughout the entire life cycle, those of Fajardo and White Pompadour are green during the first two or three weeks only and then turn light purple; while those of Camuy, Black Beauty and University are purple from the very beginning.

(4) Intense purple color of Camuy is inherited in a 3:1 ratio to Green. The same ratio exists between the green of Green and the purple of University and Black Beauty. The University purple is inherited in the same ratio in respect to Fajardo green purple striped. For all these a unit factor $\mathrm{Pr} p r$ is assumed.

(5) Green color of fruit in the crosses studied is always associated with green plant color; and purple, red and pink with purple color of plant. White corolla is always associated with green color of plant; striped anthers with a recessive factor for fruit or plant color.

(6) Red, purple and pink color of fruit is dominant over green and inherited in a 3:1 ratio. Likewise green purple striped is domi- 
nant over white purple striped and is inherited in a $3: 1$ ratio. Purple was proved to be also dominant over white purple striped. Green purple striped acts as a recessive in respect to pink or purple, but as a dominant in respect to white purple striped.

(7) Violet or purple corolla is dominant over white corolla. They stand in a $3: 1$ ratio in the $\mathrm{F}_{2}$ generation.

(8) Striping of anthers is dominant over non-striping and is inherited in a $3: 1$ ratio.

(9) A unit factor appears to exist for each of the characters; color of plant, color of fruit, color of corolla and striping of anthers. The following allelomorphic pairs of factors are assumed: plant color Pr pr, fruit color $C c$, corolla color $\mathrm{C}_{1} \mathrm{c}_{1}$, and striped character of anthers St st. A single factor might be assumed as affecting all the characters here involved.

(10) There may be complete linkage between these characters: White corolla and non-striped anthers always stand for green fruit, and green plant (all recessive characters). On the other hand striped anthers always go with bright-colored fruit and with purple plants.

(11) The composition of a green plant with white corolla, green fruit and non-striped anthers may be represented as prpr ce $\mathrm{C}_{1} \mathrm{c}_{1}$ stst, or as prpr, ce, etc.

\section{ACKNOWLEDGMENTS}

The writer gratefully acknowledges his appreciation to Dr. Melville T. Cook, pathologist, to Hon. C. E. Chardon, former Commissioner of Agriculture of Porto Rico and to Mr. F. A. López Domínguez, formerly Director of the Insular Experiment Station, for their interest and cooperation. $\mathrm{He}$ is specially indebted to Mrs. F. W. Horne of Santurce, Porto Rico, for the color drawings. Finally his thanks are due to Dr. A. C. Fraser, under whose suggestion and advice this work was undertaken and to Dr. R. G. Wiggans of the Department of Plant Breeding of Cornell University, and Dr. Thomas Bregger, Plant Breeder of the Insular Experiment Station for help in the preparation of the manuscript.

\section{CORNELL UNIVERSity, Ithaca, N. Y.}

Literature Cited

1. Bayla, A. MI. Hybridization of eggplants. Philippine Agr. 7 : 66-71. 1918.

2. Bailey, I. H. The behavior of some eggplant crosses. New York (Cornell) Sta. Bul. 49: 338-345, fig. 4. 1892.

3. Bailey, I. H. and W. IM. MIunson. Experiences with eggplants. New York (Cornell) Sta. Bul. 26: 1-20, figs. 1-14. 1891. 
4. Halsted, B. D. Experiments in crossing plants. In New Jersey Agr. Exp. Sta. Ann. Rept. 1901: 389-411.

5. Halsted, B. D. Colors in vegetable fruits. Jour. Heredity 9 : 18-23. 1918.

6. Munson, W. M. Notes on Eggplants. In Rept. of Horticulturist, Maine Agr. Exp. Sta. Ann. Rept. 1892:76-89, figs. 1-10. 1893.

7. Munson, W. M. Summary of experiments in practical horticulture. Maine Agr. Exp. Sta. Bul. 113: 1-36. 1905.

8. Owen, E. J. Report of progress. In New Jersey Agr. Exp. Sta. Ann. Rept. 1911: 389-399. 1912.

9. Owen, E. J. A study of inheritance in garden plants. In New Jersey Agr. Exp. Sta. Ann. Rept. 1912: 408-417, plates 33-38. 1913.

10. Owen, E. J. The breeding of vegetable fruits. In New Jersey Agr. Exp. Sta. Ann. Rept. 1917: 396-401. 1918.

\section{Explanation of Plates}

Plate III. Plant Color. Parents Camuy (1), and Green (2). Fig. 3 is the $\mathrm{F}_{1}$ of the cross Camuy $\times$ Green. Figs. $4-7, \mathrm{~F}_{2} \mathrm{~g}$ 'neration seedlings, $3: 1$ ratio of purples to green.

Plate IV. Corolla and anther characters, Fig. 1, corolla of Camuy, anthers striped; fig. 2, Fajardo, non-striped anthers; fig. 3, white Pampadour, non-striped anthers; fig. 4, University, striped anthers; and fig. 5, white corolla of Green, anthers non-striped.

Plate V.-Black beauty eggplant.

Plate VI.-Fajardo eggplant.

Plate VII.-University eggplant.

Plate VIII.-Left: Green eggplant, Right: White pompadour eggplant. 
署
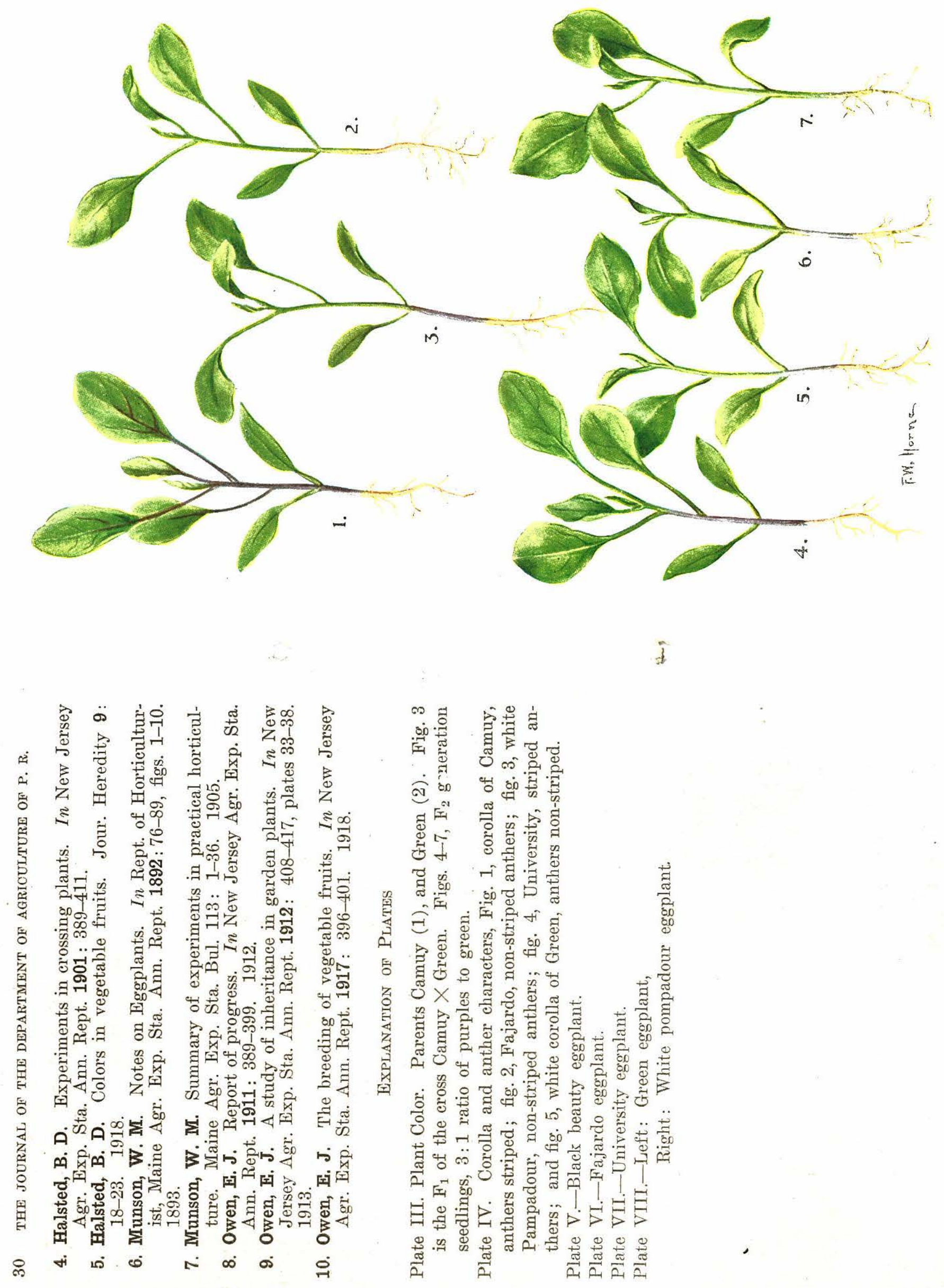
PLATE IV.

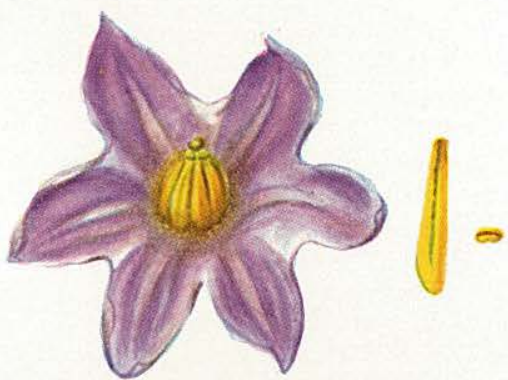

1.

(5)
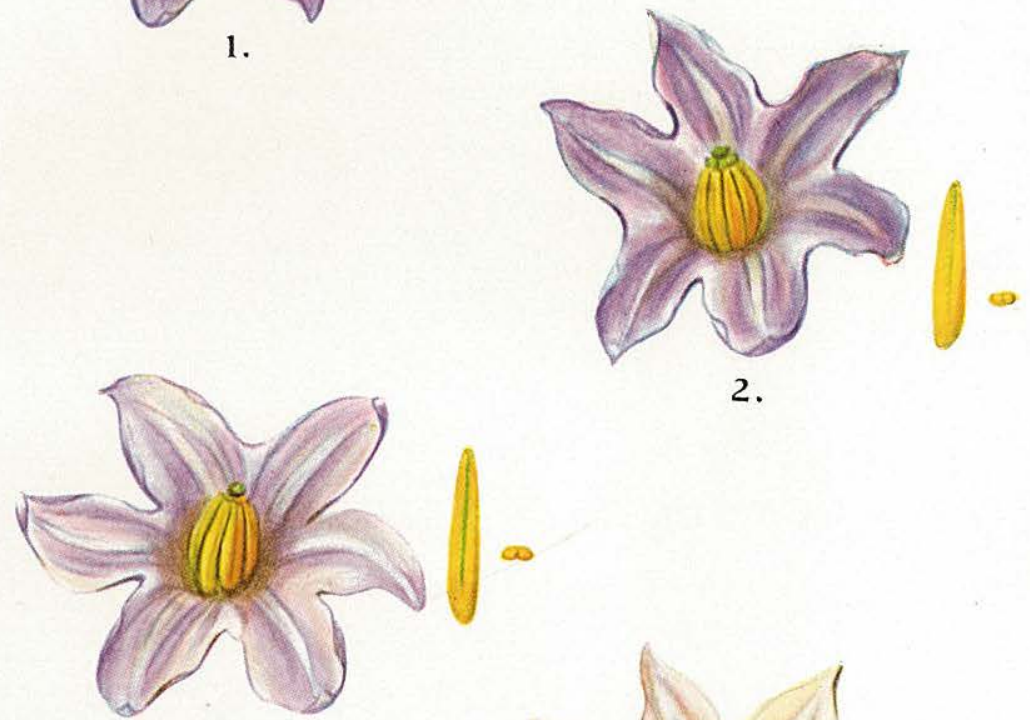

3.

St?
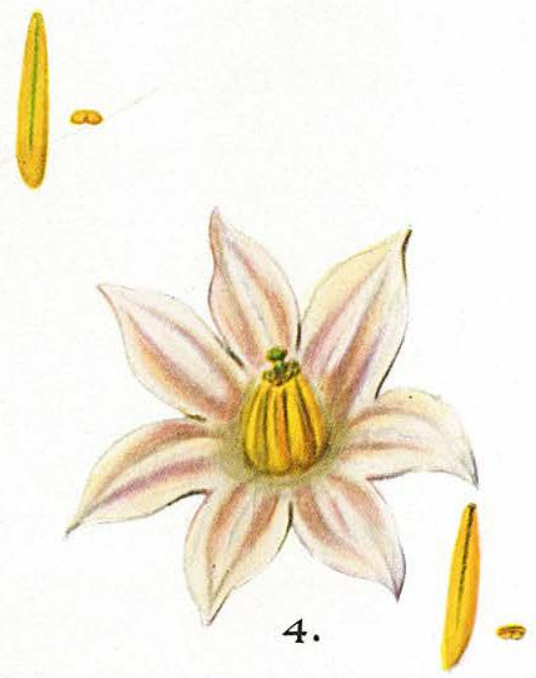

F.W. Horne (Y) 5 .

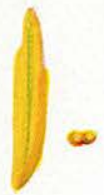




\section{PLATE V.}

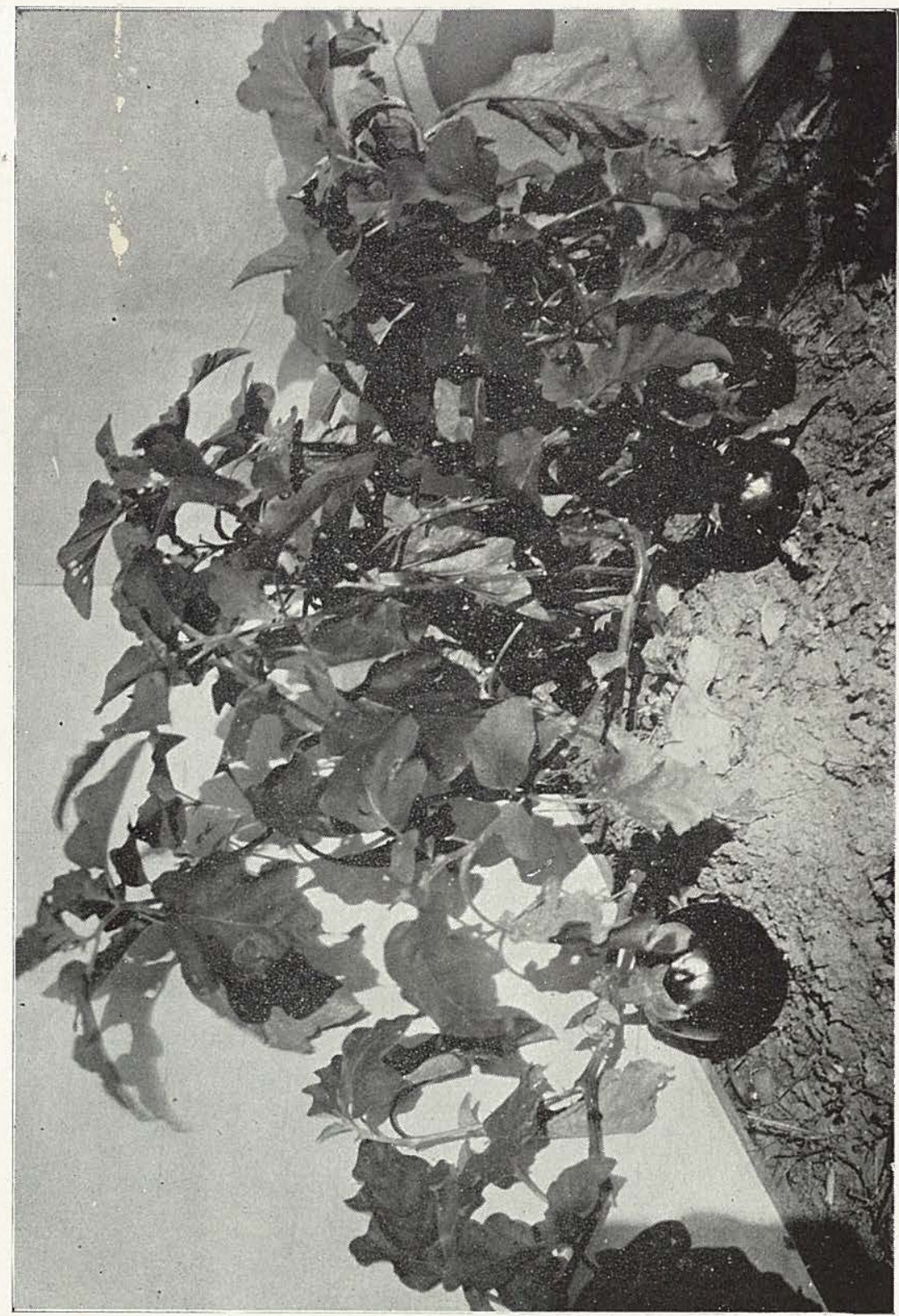


PLATE VI.

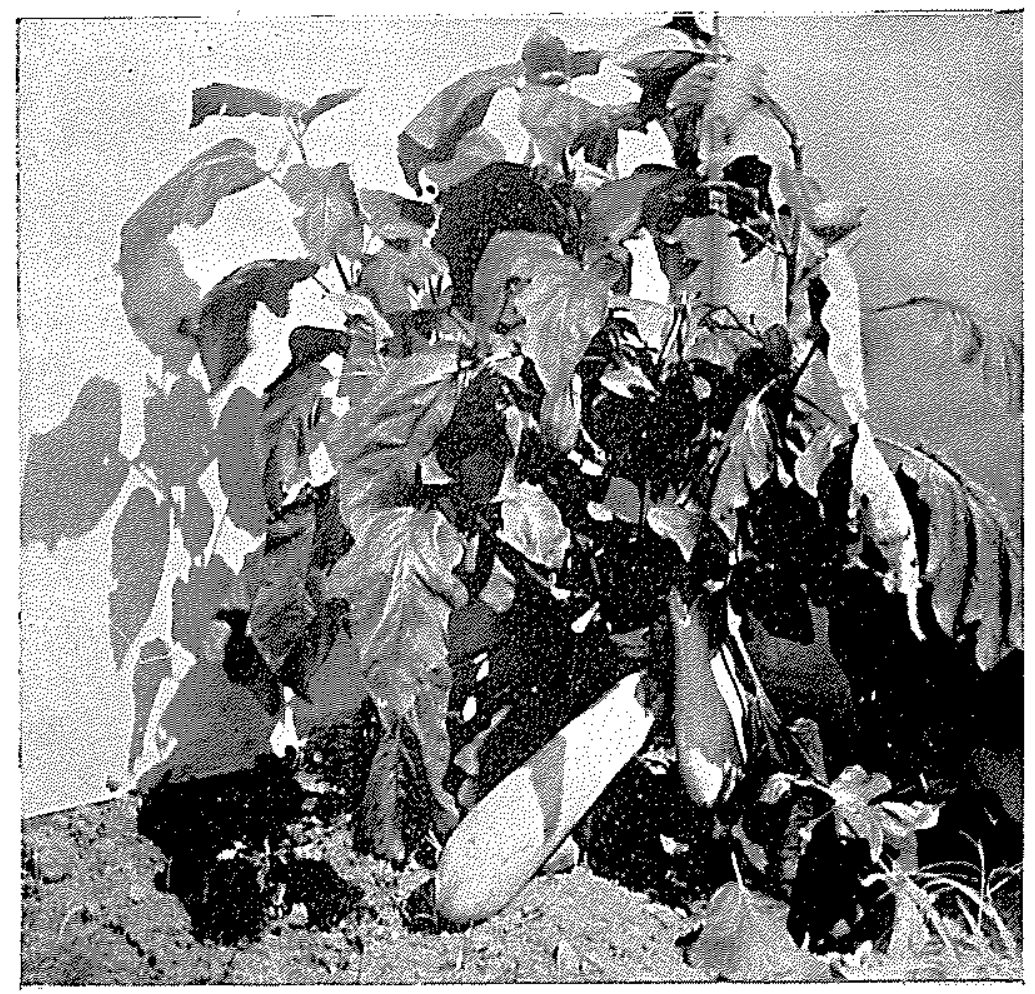




\section{PLATE VII.}

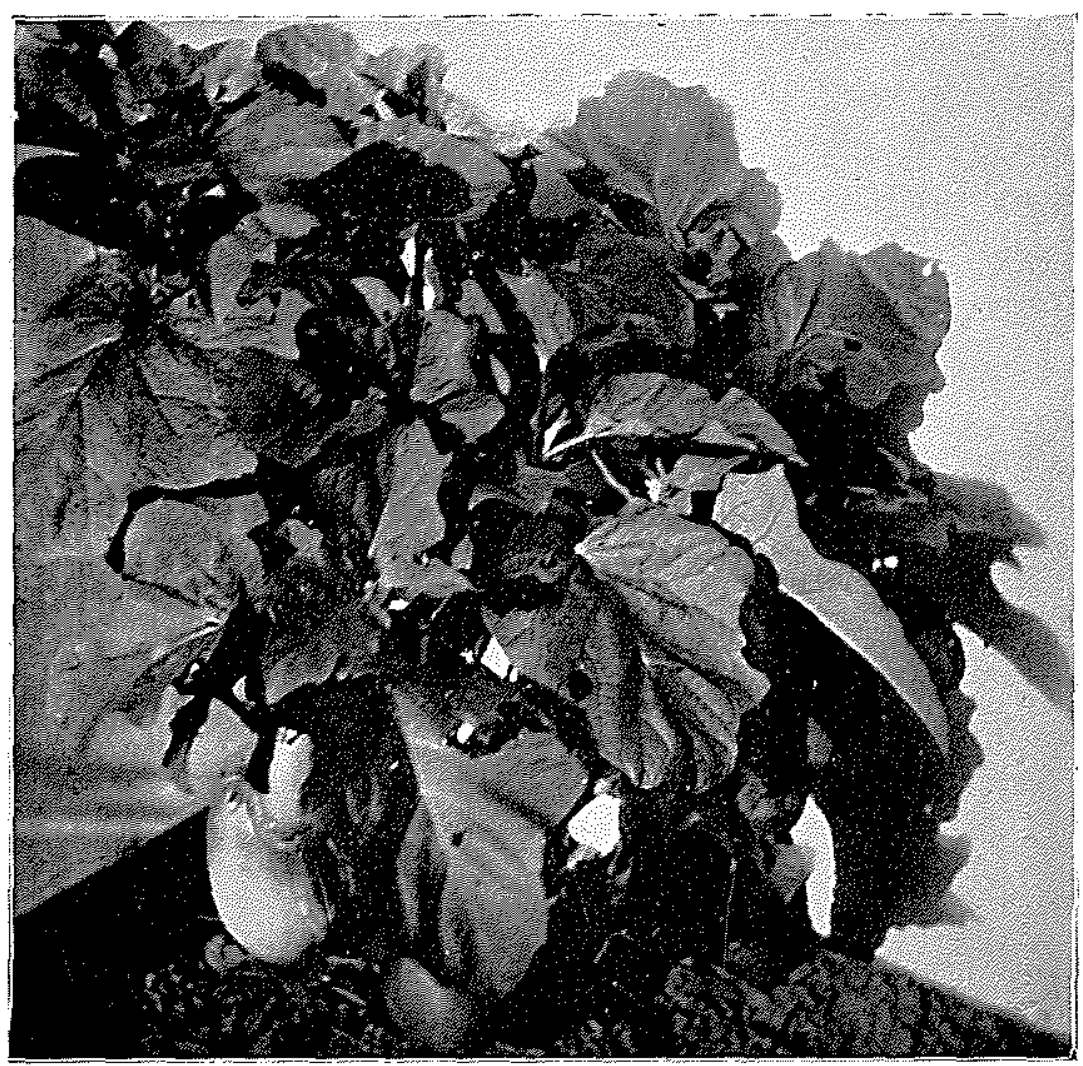




\section{PLATE VIII.}

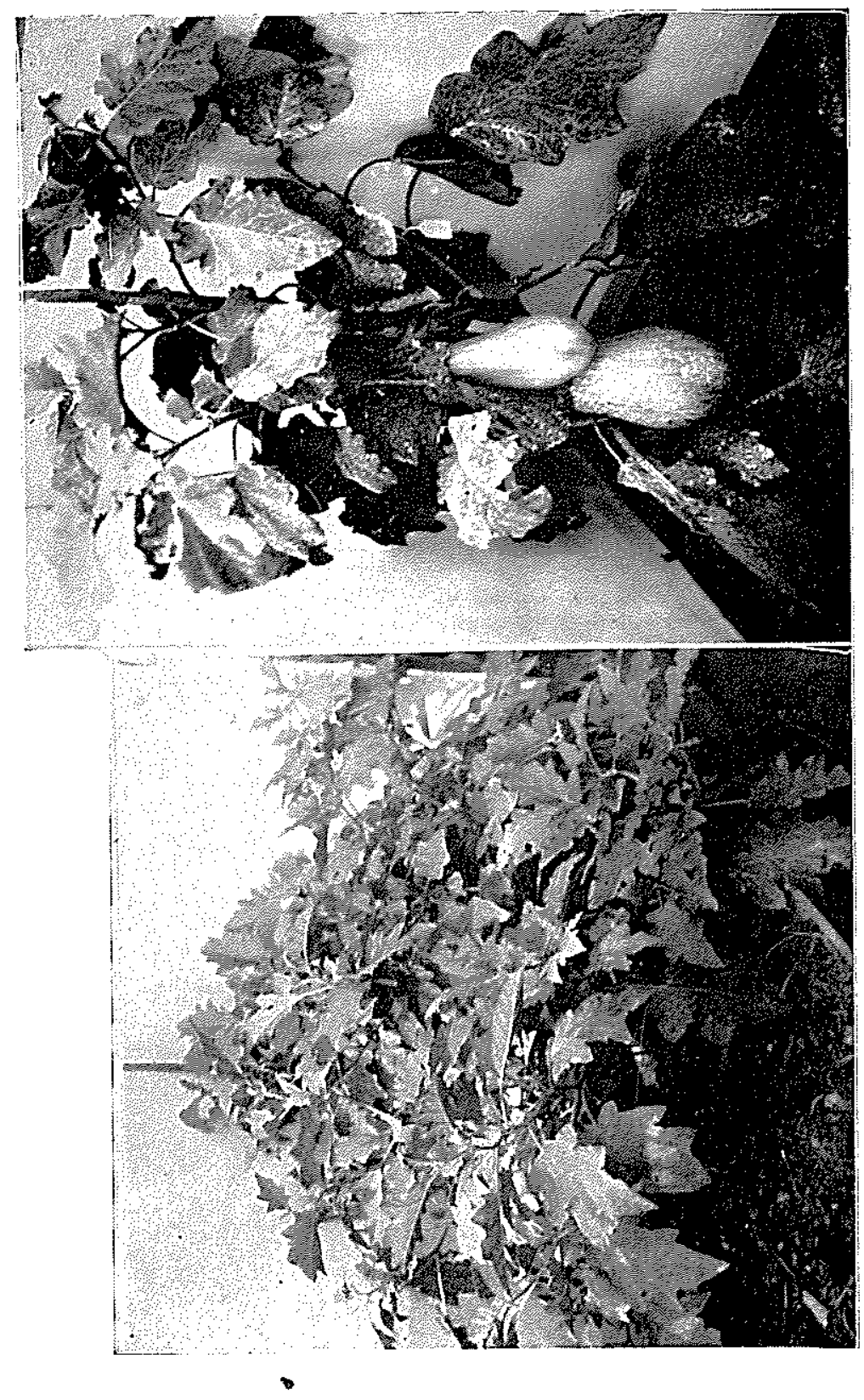

